\title{
Prolongation of inflammation in rats inoculated with adjuvant
}

\author{
Y. MIZUSHIMA \\ From the Department of Physical Therapy and Medicine, Faculty of Medicine, University of Tokyo
}

W. TSUKADA AND T. AKIMOTO

From the Biological Laboratory of Research Laboratories, Daiichi Seiyaku Co., Minamifunabori, Edogawa, Tokyo, Japan

The experimental model of rheumatoid arthritis has not yet been established, but adjuvant arthritis in rats probably resembles human rheumatoid arthritis not only clinically and histologically but also aetiologically. Adjuvant arthritis, described by Stoerk, Bieliński, and Budzilovich (1954) and studied in detail by Pearson (1956), is a syndrome induced in rats by the intradermal injection of a suspension of dead mycobacteria in liquid paraffin. The syndrome is characterized by the development of inflamed lesions followed by an intensive and chronic arthritis (so-called secondary lesions) remote from the injection site after a delay of approximately 12 days.

Most of the investigations of the mechanisms involved in the production of the disease were made by immunological approaches. Extensive studies by Pearson and Wood (1964), Waksman and Wennersten (1963), Newbould (1964), and other investigators seemed to indicate that adjuvant arthritis is an immunological disease, probably due to delayed hypersensitivity. On the other hand, few studies have been made of the inflammatory reactivity of rats inoculated with adjuvant and the influence of a non-specific inflammatory stimulus on the course of the disease.

Mechanical stress on a joint in rheumatoid patients often aggravates or exacerbates the inflammation. It is considered, therefore, that a non-specific stress or a minor inflammation induced by stress influences the process of joint inflammation. In the experiment reported below irritants such as carrageenin were injected into rats inoculated with adjuvant to determine the inflammatory reactivity of the subject and the influence of non-specific inflammation on the course of adjuvant arthritis.

\section{Material and methods}

Random-bred male rats of the Donryu strain and female rats of the Sprague-Dawley strain aged from 8 to 10 weeks and weighing 180 to $250 \mathrm{~g}$. at the beginning of experiment were used. A dose of $0.1 \mathrm{ml}$. liquid paraffin (Merck, Germany) containing $0.6 \mathrm{mg}$. of heat-killed Mycobacterium butyricum was injected intradermally to the basal part of the tail. The following irritants were injected subcutaneously into the left hind foot pad of rats preinoculated with adjuvant and untreated control animals: $0.1 \mathrm{ml}$. 1 per cent. carrageenin (Nitto Kaiso, Tokyo, Japan), $\mathbf{0} \cdot 1 \mathrm{ml} .10$ per cent. brewer's yeast, $\mathbf{0} \cdot 1$ ml. 5 per cent. formalin, $0.1 \mathrm{ml}$. 6 per cent. egg white, and $0.1 \mathrm{ml}$. of 0.03 per cent. serotonin in saline. The volume of the left hind foot was measured after the method described by Van Arman, Begany, Miller, and Pless (1965).

The swelling index of the inflamed paw was calculated as follows:

Swelling index $=$ $=\frac{\text { Vol. of swollen foot }- \text { Vol. of foot before injection }}{\text { Volume of foot before injection }} \times 100$

Histological studies The inflamed tissues fixed with 10 per cent. formalin were decalcified with 5 per cent. trichloroacetic acid and embedded in paraffin. Sections were stained with haematoxylin and eosin and with Azan-Mallory.

\section{Results}

(1) Induction of prolonged inflammation by carrageenin in rats of Donryu strain inoculated with adjuvant

Rats were inoculated with adjuvant $8,5,3$, or 2 days before the carrageenin injection. Control rats were not inoculated with adjuvant. The volume of swelling of the injected foot was measured 3,48 , and $72 \mathrm{hrs}$ after the carrageenin injection. The results are summarized in Table I (opposite). 
Table I Prolonged inflammation induced by carrageenin in rats inoculated with adjuvant Swelling index \pm standard error

Time of inoculation of adjuvant (days before carrageenin injection)

\begin{tabular}{l}
\hline No inoculation \\
\hline 2 \\
3 \\
5 \\
8
\end{tabular}

No. of rats

\begin{tabular}{l}
\hline 52 \\
\hline 43 \\
33 \\
54 \\
53
\end{tabular}

Time elapsed after carrageenin injection (hrs)

\begin{tabular}{lll}
\hline 3 & 48 & 72 \\
\hline $86 \pm 2 \cdot 0$ & $41 \pm 1 \cdot 6$ & $32 \pm 1 \cdot 7$ \\
\hline $58 \pm 1 \cdot 8^{*}$ & $41 \pm 1 \cdot 5$ & $35 \pm 0 \cdot 7$ \\
$77 \pm 1 \cdot 9^{*}$ & $51 \pm 3 \cdot 4^{*}$ & $50 \pm 5 \cdot 2^{*}$ \\
$84 \pm 2 \cdot 3$ & $64 \pm 3 \cdot 8^{*}$ & $54 \pm 3 \cdot 7^{*}$ \\
$88 \pm 2.2$ & $74 \pm 3 \cdot 6^{*}$ & $63 \pm 3 \cdot 8^{*}$
\end{tabular}

*Significance $(P<0.05)$ in relation to no inoculation group

The swelling of the inflamed foot measured 3 hours after the carrageenin injection was significantly smaller in the rats inoculated with adjuvant 2 or 3 days before the injection than in the control rats. On the other hand, the swelling of the foot measured 48 and 72 hours after the carrageenin injection was markedly larger in the rats inoculated with adjuvant 3,5 , or 8 days before the injection than in the control rats. This prolongation of inflammation was not observed in the rats inoculated with adjuvant 2 days before the injection. No swelling of the foot was observed within 10 days after the inoculation of adjuvant in 33 rats given no carrageenin injection.

A few typical courses of inflammation induced by carrageenin on the rats inoculated with adjuvant 3 days before the carrageenin injection are given in Fig. 1. The course of inflammation induced by carrageenin was divided into the following three groups:

\section{(A) NON-ARTHRITIC}

In this group the volume of swelling of the foot did not much differ from that of control rats throughout the course: $A$ in Fig. 1. The rats developed no arthritis.

\section{(B) MONOARTHRITIC AND \\ (C) POLYARTHRITIC}

In these groups the swelling was prolonged and decreased gradually or abruptly, being followed in most cases by a new increase in the swelling of the foot 8 to 11 days later (see $B$ and $C$ in Fig. 1). Since limbs which were not injected swelled simultaneously with the latter swelling of the injected foot in polyarthritic group (C), the latter swelling is considered to correspond with the secondary lesion of adjuvant arthritis. On the other hand other limbs

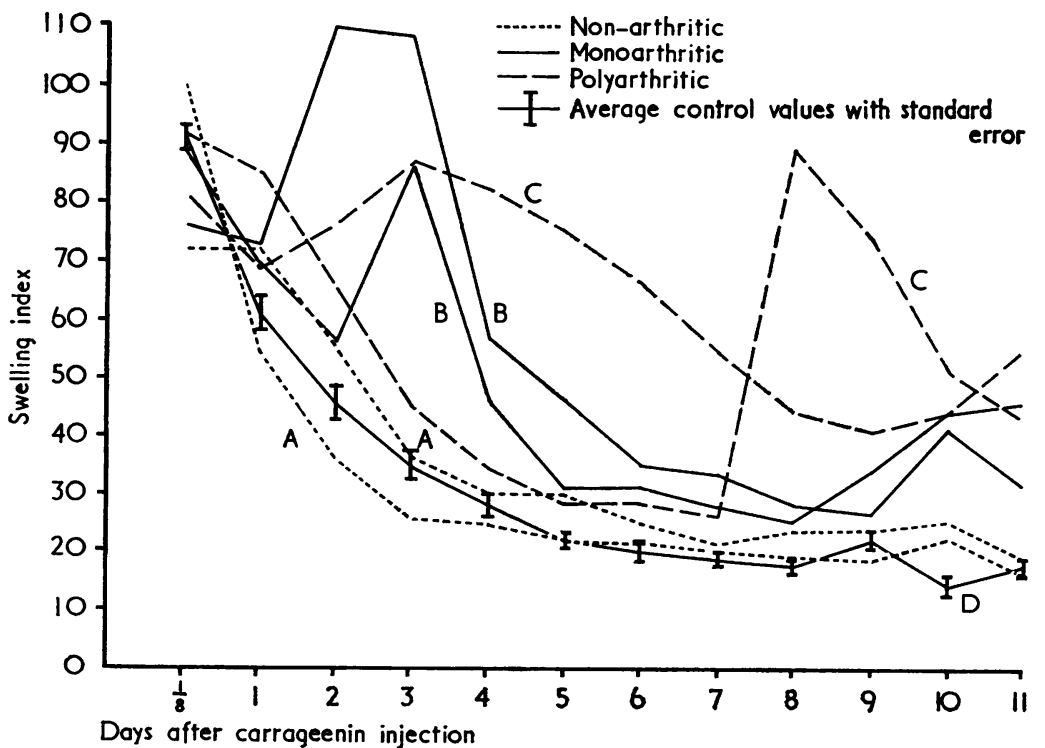

FIG. 1 Course of inflammation induced by carrageenin in rats inoculated with adjuvant 3 days before the injection.
A. Non-arthritic group B. Monoarthritic group C. Polyarthritic group
D. Average values of control group (no adjuvant inoculation) with standard error 
did not swell in monoarthritic group (B). An $x$-ray photograph of the swollen foot in this group showed similar changes in bone and cartilage to those of a foot in the polyarthritic group (Fig. 2). Therefore the swelling in the group designated 'monoarthritic' in this study is considered to correspond to the secondary lesion of adjuvant arthritis.

Histological study of the inflamed tissue of the foot 4 days after the carrageenin injection in rats in oculated with adjuvant 3 days before the injection showed an intensive infiltration of mononuclear cells with a formation of granuloma in the inflamed lesion. The histological findings differed from those in the inflamed tissue induced by carrageenin alone consisting of a very weak infiltration of cells without granuloma formation.

Relation of the prolongation of inflammation induced by carrageenin and the incidence of polyarthritis and monoarthritis in the rats inoculated with adjuvant 3 days before the carrageenin injection is summarized in Table II. As shown in the Table, the volume of swelling measured 48 and 72 hours after the carrageenin injection was significantly larger in the monoarthritic and polyarthritic group than in the non-arthritic group. This indicates that the prolongation of inflammation often occurred in the rats which developed arthritis later. On the other hand a decrease in swelling measured 3 hours after the injec-

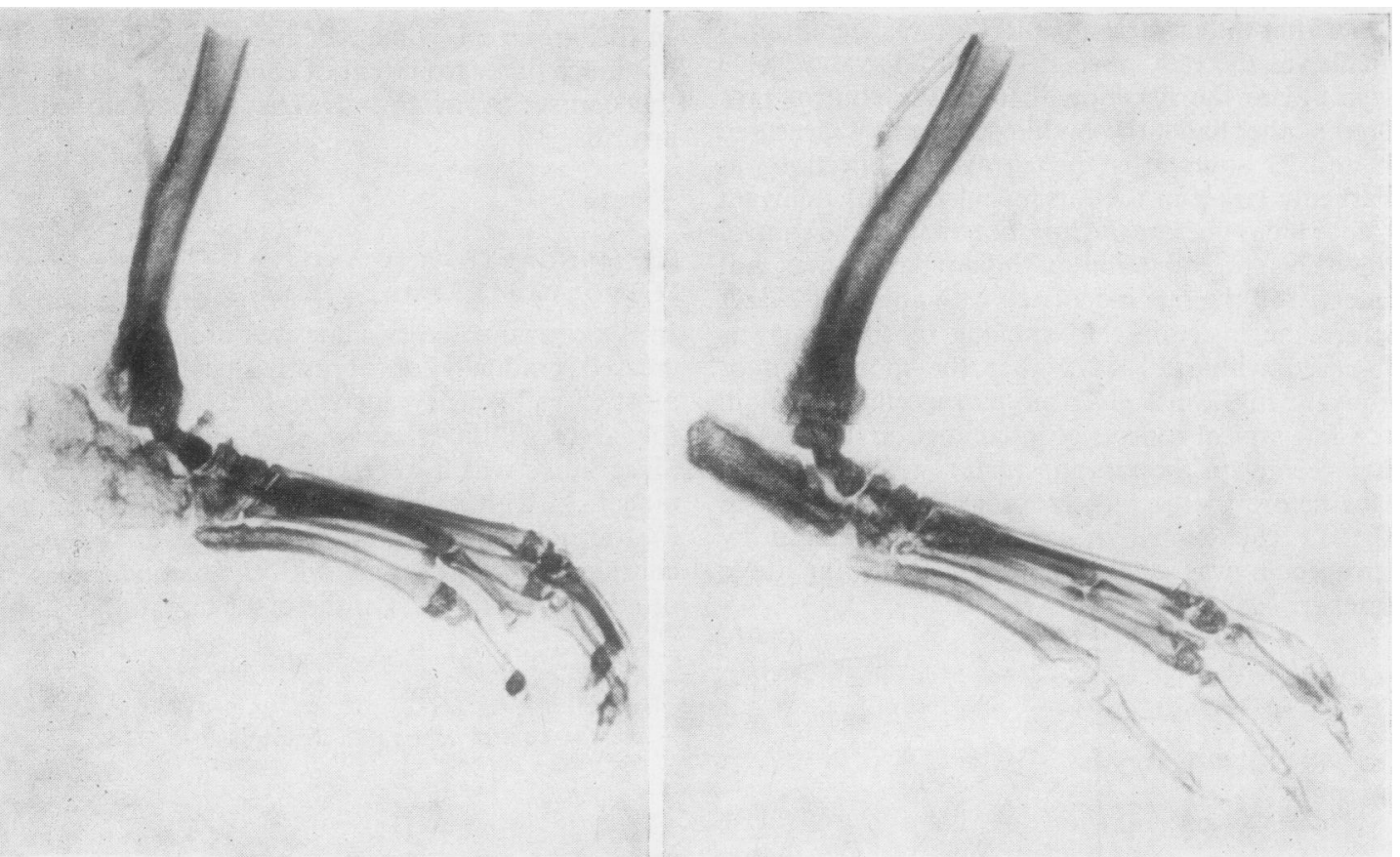

FIG. $2 X$-ray photograph, showing monoarthritis and polyarthritis

LEFT: Monoarthritis, 31 days after adjuvant inoculation and 28 days after carrageenin injection.

RIG HT : Polyarthritis, 29 days after adjuvant inoculation, no carrageenin injection.

Table II Relation of prolongation of inflammation induced by carrageenin with incidence of polyurthritis and monoarthritis in rats inoculated with adjuvant 3 days before the injection

Swelling index \pm standard error

\begin{tabular}{|c|c|c|c|c|c|}
\hline \multirow[t]{2}{*}{ Group } & \multirow[t]{2}{*}{ No. of rats } & \multicolumn{4}{|c|}{ Time elapsed after carrageenin injection } \\
\hline & & $3 h r s$ & 48 hrs & 72 hrs & 14 days \\
\hline Control & 52 & $86 \pm 2 \cdot 0$ & $41 \pm 1 \cdot 6$ & $32 \pm 1 \cdot 7$ & No arthritis \\
\hline $\begin{array}{l}\text { A } \\
\text { B } \\
\text { C }\end{array}$ & $\begin{array}{r}16 \\
6 \\
11\end{array}$ & $\begin{array}{l}73 \pm 2 \cdot 5 ! \\
81 \pm 2 \cdot 5 \\
81 \pm 3 \cdot 9\end{array}$ & $\begin{array}{l}41 \pm 2 \cdot 7 \\
63 \pm 12 \cdot 0^{*} \\
58 \pm 4 \cdot 8^{*}\end{array}$ & $\begin{array}{l}36 \pm 4 \cdot 1 \\
56 \pm 13 \cdot 5 * \\
65 \pm 5 \cdot 7^{*}\end{array}$ & $\begin{array}{l}\text { No arthritis } \\
\text { Monoarthritis } \\
\text { Polyarthritis }\end{array}$ \\
\hline
\end{tabular}

*Significance $(P<0.05)$ in relation to Group $A$

tSignificance $(P<0.05)$ in relation to control group 
tion was prominent in the non-arthritic group. The influence of carrageenin injection on the incidence of polyarthritis and monoarthritis in rats inoculated with adjuvant is summarized in Table III. Observations were made 3 weeks after the inoculation. Incidence of polyarthritis was 30 per cent. in the control rats. The incidence of polyarthritis did not differ so much in the rats injected with carrageenin 2 to 8 days after the inoculation. However, a tendency to a decrease in incidence was noticed in the 5 and 8 days groups.

Monoarthritis was observed only in the treated groups and the incidence was increased in the 5 and 8 days groups. The incidence of total arthritis (sum of incidence of polyarthritis and monoarthritis) was significantly high in the 3,5 , and 8 days groups, as compared with the control group. Inflammation at the paw injected with carrageenin was always most intensive among the inflamed lesion in the polyarthritic group. It is considered, therefore, that the carrageenin injection induced the monoarthritis and intensified the secondary lesion in the rats inoculated with adjuvant.
(2) Induction of prolonged inflammation by miscellaneous irritants in rats inoculated with adjuvant

The method of experiment was the same as in Experiment 1. Brewer's yeast, formalin, egg white, or serotonin was injected into rats of the Donryu strain inoculated with adjuvant 5 or 8 days previously. The results (Table IV) indicate that yeast and formalin also induced prolonged inflammation in rats inoculated with adjuvant as well as carrageenin. On the other hand, egg white and serotonin did not induce prolonged inflammation, although they produced an intensive swelling of the paw 1 hour after the injection.

\section{(3) Induction of prolonged inflammation by} carrageenin in rats of the Sprague-Dawley strain inoculated with adjuvant

The same experiment was carried out on rats of the Sprague-Dawley strain. The results (Table V, overleaf) show that prolonged inflammation was induced

Table III Influence of carrageenin injection on the incidence (per cent.) of polyarthritis and monoarthritis in rats inoculated with adjuvant

\begin{tabular}{|c|c|c|c|c|c|c|c|c|}
\hline \multirow{2}{*}{$\begin{array}{l}\text { Time of injection of carrageenin } \\
\text { days after inoculation) }\end{array}$} & \multirow[t]{2}{*}{ No. of rats } & \multicolumn{3}{|c|}{ Polyarthritis } & \multicolumn{3}{|c|}{ Monoarthritis } & \multirow[t]{2}{*}{ Total arthritis $\dagger$} \\
\hline & & ++ & + & Total & ++ & + & Total & \\
\hline No injection & 33 & 12 & 18 & 30 & 0 & 0 & 0 & 30 \\
\hline $\begin{array}{l}2 \\
3 \\
5 \\
8\end{array}$ & $\begin{array}{l}44 \\
33 \\
54 \\
53\end{array}$ & $\begin{array}{l}9 \\
9 \\
9 \\
9\end{array}$ & $\begin{array}{l}16 \\
24 \\
13 \\
11\end{array}$ & $\begin{array}{l}25 \\
33 \\
22 \\
21\end{array}$ & $\begin{array}{r}0 \\
3 \\
6 \\
11\end{array}$ & $\begin{array}{r}9 \\
15 \\
24 \\
27\end{array}$ & $\begin{array}{r}9 \\
18 \\
30 \\
38\end{array}$ & $\begin{array}{l}34 \\
52^{*} \\
52^{*} \\
58^{*}\end{array}$ \\
\hline No adjuvant inoculation & 52 & 0 & $\mathbf{0}$ & 0 & 0 & $\mathbf{0}$ & 0 & $\mathbf{0}$ \\
\hline
\end{tabular}

* Significance $(\mathrm{P}<0.05)$ in relation to no injection group

+ Sum of incidence of polyarthritis and monoarthritis

Table IV Prolonged inflammation induced by miscellaneous irritants in rats inoculated with adjuvant (Difference of swelling index (inoculated group-control group))

\begin{tabular}{|c|c|c|c|c|c|}
\hline \multirow[t]{2}{*}{ Irritant } & \multirow{2}{*}{$\begin{array}{l}\text { Time of inoculation of adjuvant } \\
\text { (days before irritant injection) }\end{array}$} & \multirow[t]{2}{*}{ No. of rats } & \multicolumn{3}{|c|}{ Time elapsed after irritant injection (hrs) } \\
\hline & & & 3 & 48 & 72 \\
\hline Carrageenin & $\begin{array}{l}5 \\
8\end{array}$ & $\begin{array}{l}54 \\
53\end{array}$ & $\begin{array}{r}-2 \\
2\end{array}$ & $\begin{array}{l}23^{*} \\
33^{*}\end{array}$ & $\begin{array}{l}22^{*} \\
31^{*}\end{array}$ \\
\hline Yeast & 5 & 11 & 9 & $17^{*}$ & $17^{*}$ \\
\hline Formalin & $\begin{array}{l}5 \\
8\end{array}$ & 10 & $\begin{array}{l}2 \\
0\end{array}$ & $\begin{array}{c}5 \\
19^{*}\end{array}$ & $\begin{array}{l}7 \\
18^{*}\end{array}$ \\
\hline Egg white & 5 & 10 & -9 & -3 & -3 \\
\hline Serotonin & $\begin{array}{l}5 \\
8\end{array}$ & $\begin{array}{l}10 \\
10\end{array}$ & -8 & $\begin{array}{l}0 \\
6\end{array}$ & $\begin{array}{l}1 \\
5\end{array}$ \\
\hline
\end{tabular}


Table V Prolonged inflammation induced by carrageenin in rats of Sprague-Dawley strain inoculated with adjuvant (Swelling index \pm standard error)

Time of inoculation

(days before carrageenin injection)

\begin{tabular}{ll}
\hline No inoculation & \\
\hline 2 & 20 \\
3 & 10 \\
5 & 19 \\
8 & 10 \\
& 11
\end{tabular}

No of rats
Time elapsed after carrageenin injection (hrs)

\begin{tabular}{lll}
\hline 3 & 48 & 72 \\
\hline $106 \pm 3 \cdot 0$ & $39 \pm 2 \cdot 3$ & $33 \pm 2 \cdot 5$ \\
\hline $96 \pm 4 \cdot 1$ & $43 \pm 3 \cdot 0$ & $46 \pm 2 \cdot 7^{*}$ \\
$102 \pm 2 \cdot 6$ & $54 \pm 4 \cdot 4^{*}$ & $53 \pm 5 \cdot 3^{*}$ \\
$110 \pm 5 \cdot 5$ & $54 \pm 3 \cdot 4^{*}$ & $52 \pm 3 \cdot 4^{*}$ \\
$107 \pm 4 \cdot 3$ & $77 \pm 11 \cdot 2^{*}$ & $73 \pm 12 \cdot 9^{*}$
\end{tabular}

* Significance $(P<0.05)$ in relation to no inoculation group

by carrageenin in rats of the Sprague-Dawley strain inoculated with adjuvant as well as in rats of the Donryu strain.

\section{Discussion}

The prolonged inflammation induced by carrageenin found in this study in the rats inoculated with adjuvant may be a part of adjuvant arthritis or may be a prolongation of carrageenin oedema. The former explanation appears to be the more likely because:

(1) The histological findings in the cases of prolonged nflammation differed from that of carrageenin oedema.

(2) Carrageenin oedema induced in the rats inoculated with adjuvant 3 days before the injection decreased in volume within several hours after the injection, and increased again about 2 days later as shown in the Figure.

The fact that a period of remission was observed between the prolonged inflammation and the arthritis in most of the rats inoculated with adjuvant 3 days before the carrageenin injection seems. however, to support the latter possibility.

It is interesting that the abnormally prolonged inflammation induced by carrageenin in rats inoculated with adjuvant was observed as early as 5 days after the injection. A significant prolongation of the inflammation was noticed 2 days after the carrageenin injection in rats inoculated with adjuvant 3 days before the injection (Table I). Many experiments proved that the onset of the secondary lesion of adjuvant arthritis usually occurs about the 10th to the 14th post-inoculation day and never before the 9th day, except when a method of passive transfer is used, as reported by Pearson and Wood (1964) and Waksman and Wennersten (1963).

This study indicates that certain changes had already started in rats inoculated with adjuvant by the 5th post-inoculation day which could produce adjuvant arthritis or an abnormal inflammatory reaction. Some chemical changes of serum, including an elevation of acute phase reactant, have been observed at an early stage of adjuvant arthritis
(Glenn and Kooyers, 1966; Gralla and Wiseman, 1968), but were thought to be associated with the primary lesion of adjuvant arthritis. Glenn and Gray (1965) reported that reactions to carrageenin were not altered in rats inoculated with adjuvant, but they measured the intensity of the carrageenin oedema only 6 hours after the injection.

The incidence of adjuvant arthritis in the rats used was relatively low. The prolonged inflammation rarely occurred in rats in which mono- or polyarthritis did not develop later (Table II). This suggests the presence of some common factors which produced both the prolonged inflammation and the adjuvant arthritis. As shown in Table III, monoarthritis was induced by the carrageenin injection in the rats inoculated with adjuvant. The monoarthritis seemed to inhibit the development of polyarthritis in some rats inoculated with adjuvant 5 and 8 days before the carrageenin injection. Furthermore, arthritis was most intensive in the paw injected with carrageenin in the polyarthritis group. Glenn and Gray (1965) reported that a local trauma to joints 7 days after adjuvant inoculation increased the intensity of adjuvant arthritis. The use of a mixture of oscillating and direct electric current on a hind foot pad was reported to produce an intensive adjuvant arthritis (Courtright and Kuzell, 1965). Stulbarg, Einstein, Van Schoote, and Kulka (1967) observed that a mechanical stress resulting from excessive motion of an extremity localized and intensified adjuvant arthritis. It may be concluded, therefore, that local stress to the joints intensifies and, in some cases, localizes adjuvant arthritis.

Prolonged inflammation was induced in rats inoculated with adjuvant by the injection of brewer's yeast and formalin as well as carrageenin, but not by that of serotonin and egg white. It seems, therefore, that certain cells or components in body fluid which appeared at the site of inflammation induced by the former irritants and did not appear in the latter cases influenced the development of prolonged inflammation. 
The early stage of carrageenin oedema measured 3 hours after the injection was suppressed in the rats inoculated with adjuvant 2 or 3 days before the injection. Since Robinson and Robson (1966) as well as other researchers reported the production of anti-inflammatory factors at the site of inflammation, the suppression of carrageenin oedema might be due to the influence of the primary lesion caused by the direct action of the inoculated adjuvant. The localization of adjuvant arthritis at the site of carrageenin oedema described above might be also explained by the same theory.

\section{Summary}

Carrageenin and other irritants were injected into the hind paw of rats inoculated with adjuvant to find out the influence of a non-specific inflammation on the course of adjuvant arthritis and to study any alteration in the inflammatory reaction.

The early stage of carrageenin oedema was suppressed in the rats inoculated with adjuvant 2 or 3 days before the carrageenin injection. On the other hand the carrageenin injection induced a markedly prolonged inflammation in the rats inoculated with adjuvant 3,5 , or 8 days before the injection. The prolonged inflammation occurred mostly in the rats in which monoarthritis or polyarthritis developed later. The monoarthritis developed only in the paw injected with carrageenin, and the arthritis was most intense in the paw injected with carrageenin in the polyar!hritic group. The incidence of polyarthritis and monoarthritis taken together was significantly higher in the rats injected with carrageenin than in those inoculated with adjuvant only.

Prolonged inflammation was induced in rats inoculated with adjuvant by the injection of carrageenin, brewer's yeast, and formalin, but not by the injection of egg white or serotonin. This prolonged inflammation was induced in rats of both the Donryu and the Sprague-Dawley strains.

These findings indicate that certain changes which had already started in rats inoculated with adjuvant by the fifth post-inoculation day, led to adjuvant arthritis or to an abnormal inflammatory reaction of the tissues, and that some forms of non-specific inflammation induce and intensify adjuvant arthritis.

\section{References}

Courtright, L. J., AND Kuzell, W. C. (1965) Ann. rheum. Dis., 24, 360 (Sparing effect of neurological deficit and trauma on the course of adjuvant arthritis in the rat).

GlenN, E. M., AND Gray, J. (1965) Amer. J. vet. Res., 26, 1180 (Adjuvant-induced polyarthritis in rats: biologic and histologic background).

- AND KoOYERS, W. M. (1966) Life Sci., 5, 619 (Plasma inflammation units: an objective method for investigating effects of drugs on experimental inflammation).

Gralla, E. J., AND Wiseman, E. H. (1968) Proc. Soc. exp. Biol. (N.Y.), 128, 493 (The adjuvant arthritic rat: inflammatory parameters during development and regression of gross lesions).

Newbould, B. B. (1964) Ann. rheum. Dis., 23, 392 (Role of lymph nodes in adjuvant-induced arthritis in rats).

Pearson, C. M. (1956) Proc. Soc. exp. Biol. (N.Y.), 91, 95 (Development of arthritis, periarthritis and periostitis in rats given adjuvants).

— AND Wood, F. D. (1964). J. exp. Med., 120, 547 (Passive transfer of adjuvant arthritis by lymph node or spleen cells).

Robinson, B. V., AND Robson, J. M. (1966). Brit. J. Pharmacol., 26, 372 (Further studies on the anti-inflammatory factor found at a site of inflammation).

Stoerk, H. C., Bieliński, T. C., ANd Budzilovich, T. (1954) Amer. J. Path., 30, 616 (Chronic polyarthritis in rats injected with spleen in adjuvants-Abstr.).

Stulbarg, M. S., Einstein, L. P., Van Schoote, Y., and Kulka, J. P. (1967) Arthr. and Rheum., 10, 317 (Effect of exaggerated movement on the development of lesions in adjuvant disease of rats).

Van Arman, C. G., Begany, A. J., Miller, L. M., and Pless, H. H. (1965) J. Pharmacol. exp. Ther., 150, 328 (Some details of the inflammations caused by yeast and carrageenin).

Waksman, B. H., and Wennersten, C. (1963) Int. Arch. Allergy, 23, 129 (Passive transfer of adjuvant arthritis in rats with living lymphoid cells of sensitized donors). 


\section{RÉSUMÉ}

La prolongation de l'inflammation chez les rats inoculés avec l'adjuvant

La carragheen et d'autres irritants ont été injectés dans la patte de derrière des rats inoculés avec l'adjuvant afin de découvrir l'effet d'une inflammation non-spécifique sur le cours de l'arthrite causée par l'adjuvant et d'étudier n'importe quel changement de la réaction inflammatoire.

Le stade primaire de l'oedème causé par la carragheen a été supprimé chez les rats inoculés avec l'adjuvant 2 ou 3 jours avant l'injection de la carragheen, mais la carragheen a causé une inflammation plus prolongée chez les rats inoculés avec l'adjuvant 3,5 , ou 8 jours avant l'injection. L'inflammation prolongée avait eu lieu plutôt chez les rats qui ont développé plus tard une monoarthrite ou une polyarthrite. La mono-arthrite se développait seulement dans la patte qui avait reçu l'injection de carragheen, et l'arthrite était le plus marqué dans la patte injectée de carragheen dans le groupe polyarthritique. L'incidence de la polyarthrite et de la monoarthrite prises ensemble était plus élevée chez les rats injectés de carragheen que chez ceux inoculés avec l'adjuvant.

L'inflammation prolongée était causée chez les rats inoculés avec l'adjuvant par l'injection de carragheen, de levure de bière et de formaline, mais pas par l'injection du blanc d'oeuf ou de la sérotonine. Cette inflammation prolongée était causée chez les rats provenant des souches Donryu et Sprague-Dawley.

Ces observations indiquent que certains changements qui avaient déjà commencé chez les rats inoculés avec l'adjuvant avant le cinquieme jour après l'injection causaient une arthrite due a l'adjuvant ou à une réaction inflammatoire anormale des tissus, et que certains genres d'inflammation non-spécifiques induisent et intensifient l'arthrite causée par l'adjuvant.

\section{SUMARIO}

Prolongación de la inflamación en ratas inoculadas con adyuvante

Se inyectó carrageenina y otros irritantes en la pata trasera de ratas inoculadas con adyuvante para descubrir la influencia de una inflamación no específica en el curso de la artritis adyuvante y para estudiar cualquier alteración en la reacción inflamatoria.

La etapa primaria del edema causado por carrageenina fue suprimida en las ratas inoculadas con adyuvante dos o tres dias antes de la inyección de carrageenina. Por otra parte, la inyección de carrageenina produjo una inflamación notablemente prolongada en las ratas inoculadas con adyuvante 3,5 u 8 días antes de la inyección. La inflamación prolongada ocurrió principalmente en las ratas que posteriormente desarrollaron monoartritis $o$ poliartritis. La monoartritis se desarrolló solamente en la pata inyectada con carrageenina, y la artritis fue más intensa en la pata inyectada con carrageenina en el grupo poliartrítico. La incidencia de poliartritis y monoartritis, tomada en conjunto, fue significativamente más alta en las ratas inyectadas con carrageenina, que en aquellas inoculadas con adyuvante solamente.

La inflamación prolongada se produjo en ratas inoculadas con adyuvante, por la inyección de carrageenina, levadura de cerveza y formalina, pero no por la inyección de clara de huevo o serotonina. Esta inflamación prolongada fue inducida en ratas tanto de la especie Donryu como de la Sprague-Dawley. Estos descubrimientos indican que ya se habían iniciado ciertos cambios en ratas inoculadas con adyuvante al quinto día después de la inoculación, lo cual condujo a la artritis adyuvante o a una reacción inflamatoria anormal de los tejidos, y que ciertas formas de inflamación no específica inducen e intensifican la artritis adyuvante. 